\title{
Chemical composition and yield of essential oil from three Croton species
}

\author{
Giuliane Sampaio de Souza ${ }^{1}$ Oriel Herrera Bonilla ${ }^{2}$ \\ Eliseu Marlônio Pereira de Lucena $^{2}$ Yuri Pereira Barbosa ${ }^{3}$
}

\author{
${ }^{1}$ Escola de Ensino Infantil e Fundamental Dr. Alberto Feitosa Lima, Tauá, CE, Brasil. E-mail: sampaio.giuliane@gmail.com. \\ Corresponding author. \\ ${ }^{2}$ Programa de Pós-graduação em Recursos Naturais, Universidade Estadual do Ceará (UECE), Fortaleza, CE, Brasil. \\ ${ }^{3}$ Laboratório de Ecologia, Curso de Ciências Biológicas, Universidade Estadual do Ceará (UECE), Fortaleza, CE, Brasil.
}

\begin{abstract}
Marmeleiros are popularly known for the medicinal properties ascribed to their essential oils. This research aimed to analyze the essential oil of leaves from three Croton species (Croton argyrophylloides, Croton jacobinensis, and Croton sincorensis), to verify whether the daily time and harvest season in the year may interfere with their essential oils performance and composition. From each species, 1,500g of green leaves were harvested in Viçosa do Ceará - CE, at 6am and 12pm, during both dry and rainy seasons. Essential oil extraction was conducted by the method of water vapor drag and chemical profile was analyzed by gas chromatography-mass spectrometry (GC/MS). The highest yield was obtained at 12pm in the dry season for C. argyrophylloides and C. jacobinensis, and at 6am in the rainy season for C. sincorensis. Bicyclogermacrene demonstrated higher relative abundance in C. argyrophylloides (28.09 to 30.59\%), C. jacobinensis (25.2 to $30.14 \%$ ), and C. sincorensis (23.86 and $21.71 \%$ ), and the only exception was at 6am in C. sincorensis, where (E)-caryophyllene was the most abundant compound (25.34\%). The yield and composition of the studied species were influenced by rainfall, temperature, and sunlight, presenting statistical significant differences between the different periods studied. The species produce constituents with specific biological properties; and therefore, they can be used as a natural source.
\end{abstract}

Key words: marmeleiro, euphorbiaceae, bicyclogermacrene, environmental influence, crotons.

Rendimento e composição química do óleo essencial de três espécies de Croton

RESUMO: Marmeleiros são conhecidos popularmente pelas suas ações medicinais presentes em seus óleos essenciais. A pesquisa objetivou analisar o óleo essencial de folhas de três espécies de Croton (Croton argyrophylloides, Croton jacobinensis, and Croton sincorensis), a fim de verificar se os horários e periodos do ano causam diferenças no rendimento e na composição. Foram coletadas $1500 \mathrm{~g}$ de folhas verdes de cada espécie em Viçosa do Ceará - CE, às 6 e 12 horas, no período das estações seca e das chuvas. A extração ocorreu pelo método de arraste a vapor de água e a composição foi analisada por cromatografia gasosa acoplada a espectrometria de massa (CG/EM). O maior rendimento de C. argyrophylloides e C. jacobinensis foi no período seco às $12 \mathrm{~h}$, e de C. sincorensis foi no período chuvoso às 6 h. O biciclogermacreno apresentou maior concentração em C. argyrophylloides (28,09 a 30,59\%), C. jacobinensis (25,2 a 30,14\%) e C. sincorensis (23,86 e 21,71\%), com exceção do C. sincorensis às 6 h sendo o majoritário o (E)-cariofileno (25,34\%). O rendimento e a composição das espécies estudadas foram influenciadas pela pluviosidade, temperatura e incidência solar, apresentando diferença estatística entre os horários estudados. As espécies produzem constituintes com propriedades biológicas especificas, podendo ser utilizadas como fonte natural dos mesmos.

Palavras-chave: marmeleiro, euphorbiaceae, biciclogermacreno, influência ambiental, crotons.

\section{INTRODUCTION}

The genus Croton L. has the fourth genus with the largest number of species in Brazil, with 316 species. In Caatinga, it is possible to find 62 of those species (CORDEIRO et al., 2015), and the greatest dispersion was reported in the northeast, where large plant populations of quince, canopy, or canelas can be found in the secondary vegetation, mainly of the Caatinga, (CRAVEIRO et al., 1981). Species of this genus are known for their use in popular medicine (BORBA \& MACEDO, 2006). 
Medicinal and aromatic plants present biochemical and physiological alterations capable of modifying the biosynthetic pathways of biologically active substances, both qualitatively and quantitatively, thereby directly influencing the yield and the quality of essential oils (TAIZ \& ZEIGER, 2009). Environmental factors can cause changes in plants throughout the day, as the aroma of each species becomes more accentuated, which suggested that the concentration of essential oil is probably influenced by the daily time; therefore, demonstrating that it may be an important factor for the production of essential oils (GOBBO-NETO; LOPES, 2007), for commercial purposes.

The objective of this research was to analyze the essential oil of leaves of three Croton species (Croton argyrophylloides, Croton jacobinensis, and Croton sincorensis) to verify whether the parameters of daily time, harvest season and rain regimes modify the chemical composition and yield of essential oils.

\section{MATERIALS AND METHODS}

The selected species for the research were Croton argyrophylloides Muell. Arg., Croton jacobinensis Baill., and Croton sincorensis Mart. Ex Muell. Arg. The exsiccates were deposited in the EAC Herbarium (Prisco Bezerra), at the Universidade Federal do Ceará under the numbers 46719,46715 , and 46716, respectively. The harvest was carried out in Viçosa do Ceará (S 03 ${ }^{\circ} 36.165^{\circ}$ and $\mathrm{W} 041^{\circ} 13.222^{\prime}$ ), located $348.8 \mathrm{~km}$ from the capital city Fortaleza, with an altitude of 685 m.a.s.l. According to the data provided by the Instituto de Pesquisa e Estratégia Econômica do Ceará (IPECE), the average rainfall in this city is $1.349 \mathrm{~mm}$, with average annual temperature between 22 and $24^{\circ} \mathrm{C}$ in most of the territory.

During the harvest period, the dry season occurred from August to December 2014, which corresponds to the period of lowest humidity, lowest rainfall, highest temperature, and highest solar radiation, according to the
Fundação Cearense de Meteorologia e Recursos Hídricos (FUNCEME). Conversely, the rainy season occurred from January to July 2015, which corresponded to the period of highest humidity, highest rainfall, lowest temperature, and lowest solar radiation, also according to FUNCEME (Figure 1).

The plant material was harvested in September 2014 (dry season period) at 6am and at $12 \mathrm{pm}$ At $4 \mathrm{pm}$, no harvest was performed due to the small amount of leaves reported in the plants. In April, May, and June 2015 (rainy season period), $1500 \mathrm{~g}$ of green leaves of adult plants of the three species were harvested at $6 \mathrm{am}, 12 \mathrm{pm}$, and $4 \mathrm{pm}$. The extraction of the essential oil was conducted in triplicate for 90 min by applying the technique of distillation by water vapor drag, in a Marconi model MA480. The oil was removed and filtered with sodium thiosulfate and stored at $-3^{\circ} \mathrm{C}$ for further calculation of yield (\%).

The experimental design was completely randomized with 27 treatments distributed in a factorial 3 (daily time: $6 \mathrm{am}, 12 \mathrm{pm}$ and $4 \mathrm{pm}$ ) $\times 3$ (species: C. argyrophylloides, C. jacobinensis and $C$. sincorensis) $\times 3$ (months: April, May and June) in three repetitions. The data was submitted to analysis of variance and the averages were compared by the Tukey test at $\alpha=0.05$ using the ASSISTAT 7.7 beta program.

The essential oil analysis of $C$. argyrophylloides, $C$. jacobinensis, and $C$. sincorensis was performed by GC/MS, with a Shimadzu GCMS QP5050 chromatograph and a DB1 capillary column $(30 \mathrm{~m} \times 0.25 \mathrm{~mm} \times 0.25 \mu \mathrm{m})$. The oven temperature was programmed to $25^{\circ} \mathrm{C}$ (3min) up to $230^{\circ} \mathrm{C}$ with a ramp of $4.0^{\circ} \mathrm{C} \mathrm{min}^{-1}$, remaining at $230^{\circ} \mathrm{C}$ for $50 \mathrm{~min}$. Helium was used as carrier gas at a constant pressure of $100 \mathrm{kPa}$ and a linear velocity of $1.7 \mathrm{~mL} \mathrm{~min}^{-1}$ until $210^{\circ} \mathrm{C}$ and with a pressure flow of $25 \mathrm{kPa}$. Temperature of the injector was $230^{\circ} \mathrm{C}$, and injection was set to splitless mode. The conditions for mass (MS) were: ionization source temperature: $200^{\circ} \mathrm{C}$; interface temperature: $230^{\circ} \mathrm{C}$; operating ionization energy of the detector: $70 \mathrm{eV}$; and ionization current: $0.7 \mathrm{kV}$. In addition to $\mathrm{GC} /$ 


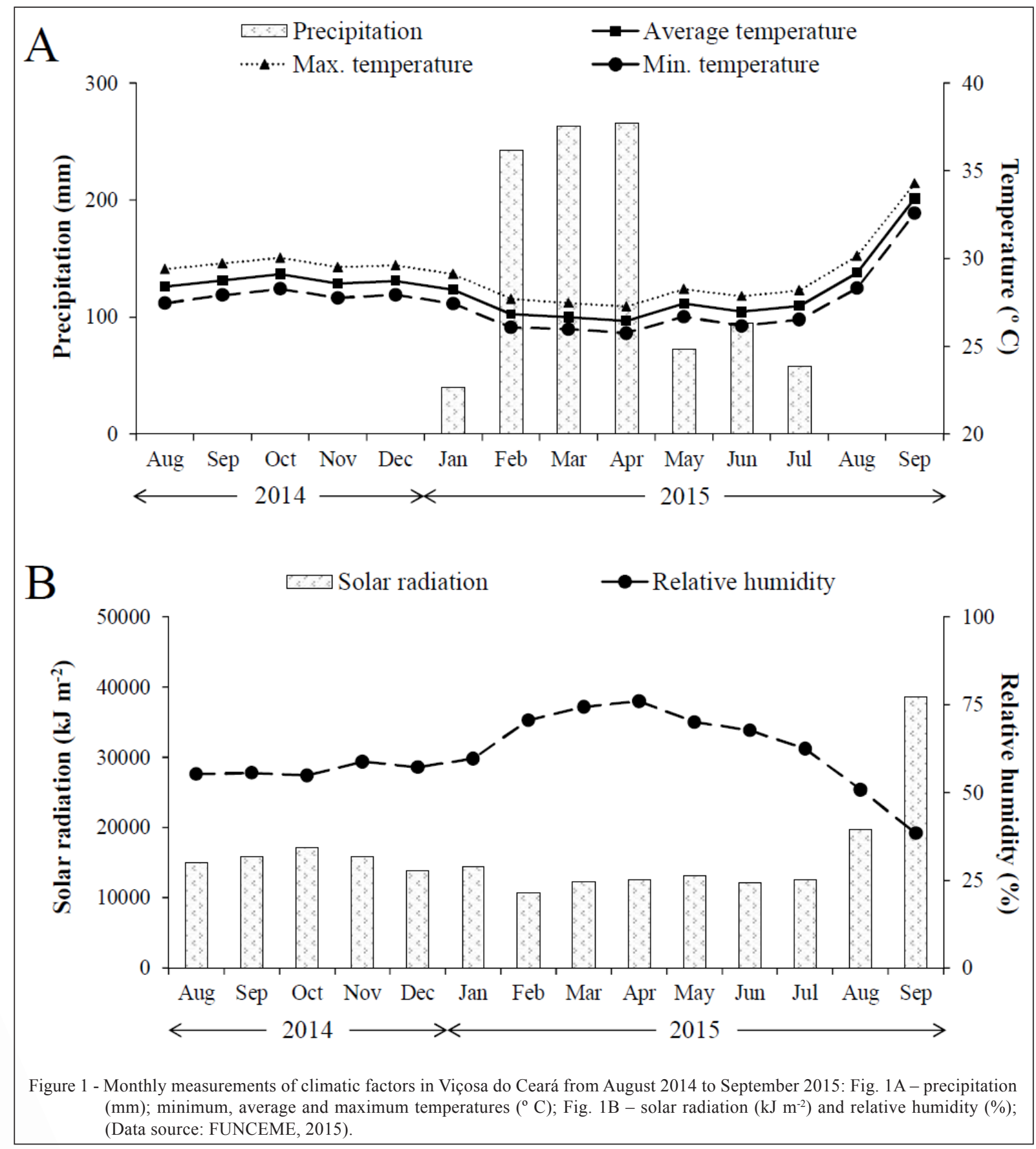

MS results, the identification of the compounds was based on the comparison of their retention indices (RI) obtained by using a homologous series of n-alkanes $\left(\mathrm{C}_{9}-\mathrm{C}_{30}\right)$. The mass spectra of the compounds was also compared with the mass spectral library Wiley spectrophotometer $275 \mathrm{~L}$ and with data from literature (ADAMS, 2001).

\section{RESULTS AND DISCUSSION}

The obtained yield of essential oils demonstrated differences between the assessed periods. The highest yield was obtained in June for C. argyrophylloides and in May for C. sincorensis during the rainy season (Table 1). In May, rainfall 
Table 1 - Yield mean values (\%) of the essential oils of Croton spp. in the rainy season for the species and according to the daily and yearly harvest times.

\begin{tabular}{|c|c|c|c|}
\hline \multirow{2}{*}{ Harvest time vs. Species } & \multicolumn{3}{|c|}{-Months-- } \\
\hline & April & May & June \\
\hline $6 \mathrm{am} \times \mathrm{Ca}$ & $0.24 \mathrm{abC}$ & $0.41 \mathrm{aB}$ & $0.64 \mathrm{aA}$ \\
\hline $6 \mathrm{am} \times \mathrm{Cj}$ & $0.12 \mathrm{dA}$ & $0.09 \mathrm{cdA}$ & $0.11 \mathrm{cA}$ \\
\hline $6 \mathrm{am} \times \mathrm{Cs}$ & $0.22 \mathrm{abcB}$ & $0.32 \mathrm{bA}$ & $0.14 \mathrm{cC}$ \\
\hline $12 \mathrm{pm} \times \mathrm{Ca}$ & $0.25 \mathrm{aB}$ & $0.47 \mathrm{aA}$ & $0.46 \mathrm{bA}$ \\
\hline $12 \mathrm{pm} \times \mathrm{Cj}$ & $0.12 \mathrm{dA}$ & $0.13 \mathrm{cdA}$ & $0.16 \mathrm{cA}$ \\
\hline $12 \mathrm{pm} \times \mathrm{Cs}$ & $0.22 \mathrm{abcA}$ & $0.18 \mathrm{cA}$ & $0.16 \mathrm{cA}$ \\
\hline $4 \mathrm{pm} \times \mathrm{Ca}$ & $0.16 \mathrm{bcdC}$ & $0.44 \mathrm{aB}$ & $0.55 \mathrm{abA}$ \\
\hline $4 \mathrm{pm} \times \mathrm{Cj}$ & 0.17 abcdA & $0.07 \mathrm{~dB}$ & $0.15 \mathrm{cA}$ \\
\hline $4 \mathrm{pm} \times \mathrm{Cs}$ & $0.14 \mathrm{cdA}$ & $0.13 \mathrm{cdA}$ & $0.18 \mathrm{cA}$ \\
\hline
\end{tabular}

Ca: Croton argyrophylloides; $\mathrm{Cj}$ : Croton jacobinensis; Cs: Croton sincorensis. Mean values followed by the same lowercase letter in the same column and uppercase in the same row do not statistically differ from each other at $\alpha=0.05$, by the Tukey test.

decreased by more than $100 \%$ as compared with April, and also presented a higher solar incidence, while there was an increase in rainfall and a reduction in solar incidence in June.

Regarding the yield of essential oil for each species, C. argyrophylloides demonstrated the highest yield for the three months under study. The highest yield for this species was obtained at $12 \mathrm{pm}$ in April (0.24\%) and May $(0.47 \%)$, and at $6 \mathrm{am}$ in June $(0.64 \%)$. The highest yield for $C$. sincorensis was obtained at 6 am in May $(0.32 \%)$.

Table 2 shows the yield of the three studied species. During the dry season, the three species demonstrated the highest yield at $12 \mathrm{pm}$. $C$. argyrophylloides showed the highest yield, both $(0.87 \%)$. This is due to the fact that essential oils often present an increase in their yield during the dry season, especially at $12 \mathrm{pm}$, when plants are exposed to a higher temperature (MORAIS, 2009).

Concerning the seasons, times, and species studied, C. argyrophylloides was the species that presented the highest yield in all the seasons and times (0.89\%). C. argyrophylloides and C. jacobinensis showed higher yields in the dry season at $12 \mathrm{pm}$, due to the higher temperature and solar incidence within the months studied, whereas $C$. sincorensis obtained higher yield during the rainy season at 6am (Table 3).

The higher yield of the essential oil of $C$. argyrophylloides and C. jacobinensis may have occurred due to the direct influence of solar incidence, which directly intervenes in the growth and development of plants (MORAIS, 2009). This result was similar to the study with the essential

Table 2 - Yield mean values (\%) of the essential oils of Croton spp. in the dry season for the species and according to the daily harvest times.

\begin{tabular}{|c|c|c|c|}
\hline \multirow{2}{*}{ Harvest time } & & pe & \\
\hline & Croton argyrophylloides & Croton jacobinensis & Croton sincorensis \\
\hline $6 a m$ & $0.74 \mathrm{bA}$ & $0.06 \mathrm{bB}$ & $0.08 \mathrm{bB}$ \\
\hline $12 \mathrm{pm}$ & $0.89 \mathrm{aA}$ & $0.22 \mathrm{aB}$ & $0.23 \mathrm{aB}$ \\
\hline
\end{tabular}

Mean values followed by the same lowercase letter in the same column and uppercase in the same row do not statistically differ from each other at $\alpha=0.01$, by the Tukey test. 
Table 3 - Yield mean values (\%) of the essential oils of Croton spp. for the harvest seasons (rainy and dry seasons), daily harvest times (6am, 12pm) and species (C. argyrophylloides, C. jacobinensis, and C. sincorensis) under study.

\begin{tabular}{|c|c|c|c|}
\hline \multirow{2}{*}{ Harvest season vs. Time } & & -Species----- & 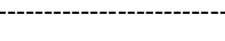 \\
\hline & Croton argyrophylloides & Croton jacobinensis & Croton sincorensis \\
\hline Rainy season - 6am & $0.41 \mathrm{cA}$ & $0.09 \mathrm{bB}$ & $0.32 \mathrm{aA}$ \\
\hline Rainy season - $12 \mathrm{pm}$ & $0.47 \mathrm{cA}$ & $0.13 \mathrm{abB}$ & $0.18 \mathrm{bcB}$ \\
\hline Dry season - 6am & $0.74 \mathrm{bA}$ & $0.06 \mathrm{bB}$ & $0.08 \mathrm{cB}$ \\
\hline Dry season - 12pm & $0.89 \mathrm{aA}$ & $0.22 \mathrm{aB}$ & $0.26 \mathrm{abB}$ \\
\hline
\end{tabular}

Mean values followed by the same lowercase letter in the same column and uppercase in the same row do not statistically differ from each other at $\alpha=0.05$, by the Tukey test.

oil of Hyptis marrubioides Epling, which demonstrated a higher yield and accumulation of biomass when the plants were cultivated in full sun (SALES et al., 2009).

Some species are more sensitive and may lose part of their yield when they are exposed to high temperatures (GOBBO-NETO \& LOPES, 2007), which explains why $C$. sincorensis had a higher yield in the rainy season.

By studying the chemical composition of the essential oil of species in the rainy season, the following constituents were identified: $C$. argyrophylloides - monoterpenes (38.3 to $42.1 \%$ ) and sesquiterpenes (52.5 to $57.2 \%)$; C. sincorensis - monoterpenes (15.7 to $28.1 \%$ ) and sesquiterpenes (56.4 to $63.7 \%$ ); C. jacobinensis - sesquiterpenes (91.3 to $93.4 \%$ ), but no monoterpenes were present in the essential oils profile. Major constituents of each species studied were identified at all harvest times. Species under study presented variation only in the concentrations of these compounds, which may have occurred due to luminosity, since the luminous intensity is a factor that influences the concentration as well as the composition of essential oils (MORAIS, 2009).

The compounds of the species C. argyrophylloides with the highest concentration were $\alpha$-pinene, spathulenol, and bicyclogermacrene (Tables 4 and 5). It is noteworthy that $\alpha$-pinene and $\beta$-pinene were also identified by BERTINI et al. (2005) in $C$. argyrophylloides as major compounds: $\alpha$-pinene with $20.96 \%$, which represents an amount similar to that reported for the harvest at $12 \mathrm{pm}$; and $\beta$-pinene with $9.55 \%$, which is higher as compared with the results reported for the other three harvest times. Therefore, the species may have a different chemical constitution, varying according to the environment where they are located.

The compounds with the highest concentration in the species $C$. jacobinensis were $\delta$-elemene, $\beta$-elemene, $(E)$-caryophyllene, and bicyclogermacrene. The compounds with higher concentration in $C$. sincorensis were $\beta$-pinene, $(E)$ caryophyllene, $\beta$-caryophyllene, spathulenol and bicyclogermacrene (Table 4 and 5).

The constituents present in the chemical profile of the studied species were also identified in the essential oil of other species within this genus, such as: in Croton sonderianus, which has $\beta$-phellandrene (18.21\%), (E)- $\beta$-guaiene (16.5\%), $\alpha$-pinene $(10.49 \%),(Z)-\beta$-guaiene $(15.92 \%)$, and (E)-caryophyllene (16.21\%) (BERTINI et al., 2005); in Croton zehntneri with (E)-anethol (88.5\%), besides others in its composition (SOUSA et al., $2005)$; in Croton isabelli with bicyclogermacrene (48.9\%), $\beta$-caryophyllene (14.3\%), and germacrene D (12.6\%); in Croton pallidulus with terpinen-4-ol (13.6\%), $\beta$-caryophyllene (11.5\%), and germacrene D $(7.6 \%)$; and in Croton ericoides with $\beta$-pinene (39.0\%) and $\beta$-caryophyllene (8.1\%) (VUNDA et al., 2012).

Regarding the species and harvest times under study, the compound with the highest concentration was bicyclogermacrene, except for the oil of $C$. sincorensis extracted at $6 \mathrm{am}$, which 
Table 4 - Volatile components (relative abundance \%) of the essential oil of Croton L. species in the rainy season.

\begin{tabular}{|c|c|c|c|c|c|c|c|c|c|c|c|}
\hline \multirow{3}{*}{ Peak } & \multirow{3}{*}{${ }^{\mathrm{A}}$ Component } & \multirow[b]{2}{*}{${ }^{\mathrm{a}} \mathrm{RI}$} & \multicolumn{3}{|c|}{ Croton argyrophylloides } & \multicolumn{3}{|c|}{ Croton jacobinensis } & \multicolumn{3}{|c|}{ Croton sincorensis } \\
\hline & & & $6 \mathrm{am}$ & $12 \mathrm{pm}$ & $4 \mathrm{pm}$ & 6am & $12 \mathrm{pm}$ & $4 \mathrm{pm}$ & 6am & $12 \mathrm{pm}$ & $4 \mathrm{pm}$ \\
\hline & & & \multicolumn{9}{|c|}{ Área \% } \\
\hline & & & ----- & Ionoterp & es hydro & rbons ( & )----- & 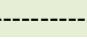 & & & $----\cdot$ \\
\hline 1 & $\alpha$-Pinene & 931 & 26.06 & 20.98 & 16.75 & n. d. & n. d. & n. d. & 10.04 & 6.19 & 4.16 \\
\hline 2 & Sabinene & 973 & 7.93 & 11.21 & 12.05 & n. d. & n. d. & n. d. & n. d. & n. d. & n. d. \\
\hline 3 & $\beta$-Pinene & 975 & 1.66 & 1.63 & 1.63 & n. d. & n. d. & n. d. & 16.56 & 14.38 & 10.81 \\
\hline \multirow[t]{2}{*}{4} & $\delta$-3-Carene & 992 & 2.53 & 2.58 & 2.25 & n. d. & n. d. & n. d. & n. d. & n. d. & n. d. \\
\hline & \multicolumn{11}{|c|}{ 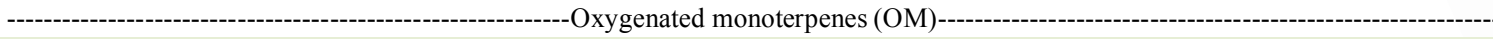 } \\
\hline 5 & 1,8-Cineole & 1025 & 2.9 & 3.71 & 4.65 & n. d. & n. d. & n. d. & 1.5 & n. d. & 0.71 \\
\hline 6 & Terpinen-4-ol & 1180 & 1.06 & 1.16 & 0.93 & n. d. & n. d. & n. d. & n. d. & n. d. & n. d. \\
\hline \multicolumn{12}{|c|}{---1 } \\
\hline 7 & $\delta$-Elemene & 1346 & 3.52 & 3.21 & 3.32 & 9.56 & 12.89 & 9.38 & 1.99 & 2.16 & 3.02 \\
\hline 8 & $\beta$-bourbonene & 1393 & n. $d$. & n. d. & n. d. & 1.76 & 1.63 & 1.96 & 1.69 & 1.1 & 1.83 \\
\hline 9 & $\beta$-Elemene & 1400 & 4.67 & 8.52 & 6.65 & 21.71 & 22.27 & 20.86 & 1.69 & 0.96 & 5.57 \\
\hline 10 & $\alpha$-Gurjunene & 1418 & n. d. & n. d. & n. d. & 0.31 & 0.43 & 0.36 & 0.53 & 1.54 & 1.79 \\
\hline 11 & (E)-Caryophyllene & 1432 & 4.15 & 3.96 & 6.36 & 10.87 & 9.4 & 8.3 & 25.34 & 11.43 & 9.74 \\
\hline 12 & Aromadendrene & 1446 & 0.46 & 0.34 & 0.48 & n. d. & n. d. & n. d. & 0.64 & n. d. & 1.66 \\
\hline 13 & $\alpha$-Humulene & 1461 & 0.66 & 0.61 & 1.03 & 7.61 & 5.34 & 6.52 & 4.91 & 2.57 & 3.25 \\
\hline 14 & allo-Aromadendrene & 1467 & 1.24 & 1.02 & 1.29 & 0.82 & 0.94 & 1.12 & 0.88 & 2.47 & 2.06 \\
\hline 15 & Germacrene D & 1487 & 3.56 & 1.43 & 1.94 & 1.1 & 0.43 & 3.15 & 7.1 & 7.98 & 9.09 \\
\hline 16 & Bicyclogermacrene & 1503 & 30.59 & 28.09 & 29.8 & 25.2 & 28 & 30.14 & 11.91 & 23.86 & 21.71 \\
\hline 17 & $\alpha$-Farnesene & 1515 & n. d. & n. d. & n. d. & 4.53 & 4.16 & 4.84 & n. d. & n. d. & n. d. \\
\hline 18 & $\delta$-Cadinene & 1524 & 0.66 & 0.45 & 0.54 & n. d. & n. d. & n. d. & 0.9 & 1.48 & 1.81 \\
\hline \multicolumn{12}{|c|}{ - } \\
\hline 19 & (E)-Nerolidol & 1567 & n. d. & 0.79 & 0.65 & 4.79 & 3.4 & 3.48 & n. d. & n. d. & 0.74 \\
\hline 20 & Spathulenol & 1574 & 2.89 & 2.77 & 3.61 & 3.04 & 2.74 & 3.29 & 1.03 & 0.87 & 1.44 \\
\hline \multirow[t]{6}{*}{21} & Caryophyllene oxide & 1579 & 1.44 & 1.31 & 1.54 & n. d. & n. d. & n. d. & 1.94 & n. d. & n. d. \\
\hline & Total identified & & 95.98 & 93.77 & 95.47 & 91.3 & 91.63 & 93.4 & 88.65 & 76.99 & 79.39 \\
\hline & $\Sigma M H$ & & 41.08 & 40.11 & 37.33 & 0 & 0 & 0 & 28.1 & 20.57 & 15.68 \\
\hline & $\Sigma O M$ & & 1.06 & 1.16 & 0.93 & n. d. & n. d. & n. d. & n. d. & n. d. & n. d. \\
\hline & $\Sigma S H$ & & 49.51 & 47.63 & 51.41 & 83.47 & 85.49 & 86.63 & 57.58 & 55.55 & 61.53 \\
\hline & $\Sigma O S$ & & 4.33 & 4.87 & 5.8 & 7.83 & 6.14 & 6.77 & 2.97 & 0.87 & 2.18 \\
\hline
\end{tabular}

${ }^{\mathrm{a}} \mathrm{RI}=$ Retention index calculated by using $\mathrm{C}_{9}-\mathrm{C}_{30}$ n-alkanes with a DB-1 column. ${ }^{\mathrm{A}}$ Listed in order of elution. n.d. $=$ not detected. Identification based on comparison with the mass spectra of the Wiley spectroscopy 275Libraries.

was the third most abundant compound. This compound was also identified as a major component of the essential oil of $C$. isabelli, which presents amoebicidal activity (VUNDA et al., 2012), hence the studied species may have amoebicidal potential. In the present study, $\beta$-pinene was the second major compound of $C$. sincorensis, which has been reported in literature as presenting antimicrobial (SILVA et al., 2012), antidepressant (GUZMÁNGUTIERREZ et al., 2012), and hypotensive properties (MENEZES et al., 2010).

It is also reported that $\alpha$-pinene, $\beta$-pinene, and 1,8-cineole, which are found in
C. argyrophylloides and C. sincorensis species, present antibacterial properties (LEITE et al., 2007). Thus, these species may be used as a source of these compounds.

\section{CONCLUSION}

Croton argyrophylloides and $C$. jacobinensis showed higher yields in the dry season at $12 \mathrm{pm}$. The metabolism of these plants works better in environments with high temperatures and solar radiation. The species $C$. sincorensis showed higher yield in the rainy season at 6am, 
Table 5 - Volatile components (relative abundance \%) of the essential oil of Croton L. species obtained in the dry season.

\begin{tabular}{|c|c|c|c|c|c|c|c|}
\hline \multirow[b]{2}{*}{ Peak } & \multirow{3}{*}{${ }^{\mathrm{A}}$ Component } & \multirow[b]{2}{*}{${ }^{\mathrm{a}} \mathrm{RI}$} & \multicolumn{2}{|c|}{ Croton argyrophylloides } & \multirow{2}{*}{$\frac{\text { Croton jacobinensis }}{6 \mathrm{am}}$} & \multicolumn{2}{|c|}{ Croton sincorensis } \\
\hline & & & $6 \mathrm{am}$ & $12 \mathrm{pm}$ & & $6 a m$ & $12 \mathrm{pm}$ \\
\hline & & & \multicolumn{5}{|c|}{ Area \% } \\
\hline \multicolumn{8}{|c|}{ 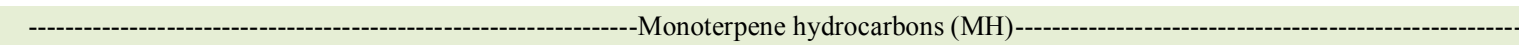 } \\
\hline 1 & $\alpha$-Pinene & 937 & 15.59 & 16.82 & 0.21 & 6.75 & 6.06 \\
\hline 2 & Sabinene & 973 & 6.95 & 6.97 & 0.09 & 4.48 & 4.05 \\
\hline 3 & $\beta$-Pinene & 975 & 1.16 & 1.29 & n. d. & 1.07 & 1.03 \\
\hline 4 & $p$-Cymene & 1023 & 2.25 & 3.07 & 0.04 & 1.82 & 2.12 \\
\hline 5 & Limonene & 1027 & 7.98 & 6.75 & n. d. & n. d. & 1.45 \\
\hline \multicolumn{8}{|c|}{ 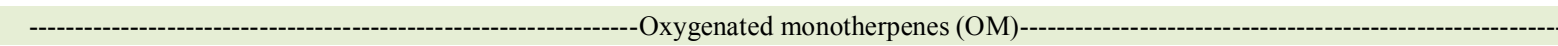 } \\
\hline 6 & 1,8-Cineole & 1030 & 7.98 & 6.75 & n. d. & 7.65 & 4.67 \\
\hline 7 & (Z)- $\beta$-Ocimene & 1047 & n. d. & n. d. & 1.27 & 0.93 & n. d. \\
\hline 8 & Terpinen-4-ol & 1181 & 1.61 & 2.02 & n. $d$. & 0.33 & 0.22 \\
\hline \multicolumn{8}{|c|}{ - } \\
\hline 9 & $\delta$-Elemene & 1343 & 0.46 & n. d. & 9.38 & n. d. & 0.59 \\
\hline 10 & $\alpha$-Copaene & 1381 & n. d. & 0.19 & 0.28 & 1.46 & 1.57 \\
\hline 11 & $\beta$-Elemene & 1397 & 4.48 & 4.37 & 17.96 & 1.11 & 1.15 \\
\hline 12 & $\beta$-Caryophyllene & 1427 & 7.65 & 4.82 & 9.28 & 18.54 & 19.2 \\
\hline 13 & $\alpha$-Humulene & 1456 & n. d. & n. d. & 4.96 & 4.03 & 4.15 \\
\hline 14 & allo-Aromadendrene & 1462 & 1.95 & 0.86 & 0.91 & 1.49 & 1.54 \\
\hline 15 & GermacreneD & 1482 & 0.64 & 0.24 & 4.13 & 5.9 & 5.23 \\
\hline 16 & $\beta$-Selinene & 1486 & 2.62 & 3.48 & 0.8 & 1.1 & 1.15 \\
\hline 17 & Bicyclogermacrene & 1497 & 7.18 & 3.83 & 20.46 & 7.17 & 6.81 \\
\hline \multicolumn{8}{|c|}{--1 } \\
\hline 18 & (Z)-Nerolidol & 1554 & 1.32 & 1.72 & 3.58 & 0.23 & 0.26 \\
\hline 19 & Spathulenol & 1572 & 12.83 & 14.02 & n. $d$. & 9.99 & 11.2 \\
\hline 20 & Caryophyllene oxide & 1575 & 3.52 & 3.26 & 5.7 & 9.89 & 9.91 \\
\hline \multirow[t]{6}{*}{21} & Viridiflorol & 1590 & 0.75 & 0.7 & 0.65 & 1.34 & 1.35 \\
\hline & Total identified & & 78.94 & 74.41 & 79.7 & 85.28 & 83.71 \\
\hline & $\Sigma M H$ & & 25.95 & 28.15 & 1.61 & 15.05 & 14.71 \\
\hline & $\Sigma O M$ & & 9.59 & 8.77 & n. d. & 7.98 & 4.89 \\
\hline & $\Sigma S H$ & & 24.98 & 17.79 & 68.16 & 40.8 & 41.39 \\
\hline & $\Sigma O S$ & & 18.42 & 19.7 & 9.93 & 21.45 & 22.72 \\
\hline
\end{tabular}

${ }^{\mathrm{a}} \mathrm{RI}=$ Retention index calculated by using $\mathrm{C}_{9}-\mathrm{C}_{30}$ n-alkanes with a DB-1 column. ${ }^{\mathrm{A}}$ Listed in order of elution by column. $\mathrm{n}$. d. $=$ not detected. Identification based on comparison with the mass spectra of the Wiley spectroscopy 275Libraries.

and this species is influenced by rainfall. Croton argyrophylloides was the most efficient species in the production of essential oil, with a yield up to five times higher than the others.

Bicyclogermacrene was the constituent that showed the highest concentration considering the species and at harvest times in study, except for $C$. sincorensis at 6am, for which (E)-caryophyllene was the major constituent. These species can be used as a source of these compounds. Chemical composition and relative percentage of these compounds varied between the studied times, influenced by temperature and solar incidence.

\section{REFERENCES}

ADAMS, R.P. Identification of essential oil components by gas chromatography quadrupole mass spectroscopy. Illinois: Allured Publishing Corporation, 2001. 456p.

BERTINI, L.M. et al. Bacterial sensitivity profile front of oils some essential Northeast Brazil plants. Infarma, v.17, n.3/4, p.80-83 2005. Available from: <http://www2.cff.org.br/ sistemas/geral/revista/pdf/17/perfil_bacterias.pdf $>$. Accessed: Jan. 24, 2015.

BORBA, A.M.; MACEDO, M. Medicinal plants used for oral health in the Santa Cruz neighborhood, Chapada dos Guimarães, Mato Grosso State, Brazil. Acta Brasílica Botany, v.20, n.4, p.771-782, 2006. Available from: <http://dx.doi.org/10.1590/ S0102-33062006000400003>. Accessed: Jan. 24,2015. 
CORDEIRO, I. et al. Croton in list of species of flora of Brazil. Jardim Botânico do Rio de Janeiro. Available from: <http:// reflora.jbrj.gov.br/jabot/floradobrasil/FB17497>. Accessed: Feb. 03, 2015 .

CRAVEIRO, A.A. et al. Essential oils of plants northeast. Fortaleza: UFC, 1981. 210p.

GOBBO-NETO, L.; LOPES, N.P. Medicinal plants: factors of influence on the content of secondary metabolites. Chemical New, v.30, n.2, p.374-381, 2007. Available from: <http://www.scielo.br/ pdf/\%0D/qn/v30n2/25.pdf>. Accessed: Jan. 28, 2015.

GUZMÁN-GUTIÉRREZ, S.L. et al. Antidepressant activity of Litsea glaucescens essential oil: Identification of $\beta$-pinene and linalool as active principles. Journal of Ethnopharmacology, v.143, n.2, p.673-679, 2012. Available from: <https://doi. org/10.1016/j.jep.2012.07.026>. Accessed: Feb. 05, 2015.

LEITE, A.M. et al. Inhibitory effect of beta-pinene, alpha-pinene and eugenol on the growth of potential infectious endocarditis causing Gram-positive bacteria. Brazilian Journal of Pharmaceutical Sciences, v.43, n.1, p.121-126, 2007. Available from: <http://dx.doi.org/10.1590/S1516-93322007000100015>. Accessed: Feb. 05, 2015.

MENEZES, I.A.C. et al. Cardiovascular effects induced by Cymbopogon winterianus essential oil in rats: involvement of calcium channels and vagal pathway. Journal of Pharmacy and Pharmacology, v.62, n.2, p.215-221, 2010. Available from: $<$ http://dx.doi.org/10.1211/jpp.62.02.0009>. Accessed: Feb. 05, 2015.
MORAIS, L.A.S. Influence of abiotic factors on the chemical composition of the essential oils. Brazilian Horticulture, v.27, n.2, p.S4050-S4063, 2009. Available from: <http://www. abhorticultura.com.br/eventosx/trabalhos/ev_3/P_4_Palestra_ Resumo_Lilia_Ap.pdf>.Accessed: Jan. 24, 2015.

SALES, J.F. et al. Biomass accumulation, foliar content of nutrients and yeld of essential oil of hortelã- do- campo (Hyptis marrubioides epl.) cultivated under organic fertilization. Semina: Agricultural Sciences, v.30, n.2, p.389-396, 2009. Available from: $<$ http://www.seer.ufu.br/index.php/biosciencejournal/article/ view/6785/4479>. Accessed: Jan. 20, 2015

SILVA, A.C.R. et al. Biological activities of $a$-pinene and $\beta$-pinene enantiomers. Molecules, v.17, n.6, p.6305-6316, 2012. Available from: <http://dx.doi.org/10.3390/molecules 17066305>. Accessed: Feb. 12, 2015.

SOUSA, E.M.B.D. et al. Extraction of volatile oil from Croton zehntineri Pax et Holf with pressurized $\mathrm{CO}_{2}$ : solubility, composition and kinetics. Journal of Food Engineering, v.69, n.3, p.325-333, 2005. Available from: <https://doi.org/10.1016/j. jfoodeng.2004.08.023>. Accessed: Feb. 12, 2015.

TAIZ L; ZEIGER E. Plant physiology. 4.ed. Porto Alegre: Artmed, 2009. 719p.

VUNDA, S.L.L. et al. Chemical composition and amoebicidal activity of Croton pallidulus, Croton ericoides, and Croton isabelli (Euphorbiaceae) essential oils. Parasitology Research, v.111, n.3, p.961-966, 2012. Available from: <http://dx.doi.org/10.1007/ s00436-012-2918-6>. Accessed: Jan. 28, 2015. 